\title{
Mexican Law of Religion at 28 Years of the Constitutional Reform on Religious Matters
}

\author{
María Concepción Medina González
}

\begin{abstract}
In the framework of the centenary of the promulgation of the Political Constitution of the United Mexican States (1917), the current directions of Mexican Law of Religion are addressed. The starting point is the constitutional reform of January 28, 1992, to Articles 3, 5, 24, 27, and 130, which are the basis for the development of a Law of Religion in a positive sense. This reform contains the principles that guarantee the freedom of religion in Mexico: separation between State and churches and Laicity of State. "Mexican Law of Religion" means the totality of state legal norms that include the religious factor linked to individual, corporate, and collective religious needs and interests under the fundamental principles of religious freedom, secularism (laicity), and separation of the State and religious communities. In this sense, the holders of the religious factor are not only the individual person and the religious communities or religious associations but also the indigenous peoples. For the analysis, I will focus my remarks on some fundamental topics: the amendments to Articles 24 and 40 of the Political Constitution and the New Constitution of Mexico City; development and legal protection of the dimensions of religious freedom; management of religious diversity as public policy and recent cases, such as the Native American Church case and the Blood Transfusion case, since these illustrate the Supreme Court's readiness to protect the right of religious freedom. One of the most difficult issues to resolve with respect to the register of religious associations has been how to define "notorio arraigo." The Basic Law strives to protect religious freedom and to establish a society tolerant of religious difference. Furthermore, increased protection of religious minorities may signal a change in Mexican cultural perceptions of religious minorities.
\end{abstract}

Keywords Freedom of religion - Secularity of state $\cdot$ Mexican law of religion • Religious associations $\cdot$ Religious pluralism

M. C. Medina González (凶)

National Autonomous University of Mexico, Mexico City, Mexico

e-mail: mariamarianita@hotmail.com 


\section{Introduction}

Mexico is not a place of religious monoculture. In Mexico, there is true religious pluralism. Although a majority of Mexicans declares to profess the Catholic religion, the presence of other religions is extensive. The Mexican secular (lay = laico) State has the enormous task of managing the religious diversity, and with the Mexican law of religion, ${ }^{1}$ to take up the challenge of guarantying the full exercise of religious freedom, without constituting ghettos or any type of segregation, to make peaceful religious coexistence possible.

The basis for the legal relationship between State and church is to be found in the Mexican Constitution of 1917. Since that date, there have been amendments to Articles 24 and 130 on few but important occasions. Before constitutional reform of January 28, 1992, Articles 24 (at the time freedom of belief) and 130 (at the time Supremacy of State on Church) contained anti-clerical provisions, religious associations could not obtain legal personality and the principle of Supremacy of State on church predominated.

With the constitutional reform of January 28, 1992 to Articles 3 (right of education), 24 (at the time freedom of belief), 27 (right of property) and 130 (at the time Supremacy of State on church), several anti-clerical provisions were derogated, religious communities and churches could obtain legal personality as "religious associations" (asociaciones religiosas) by the Ministry of Interior.

This constitutional reform showed several processes such as: construction of laicity on the recognition of religious diversity, the visibility of the "religious minorities" at the possibility to be registered as religious associations and obtain legal personality, and recognition of religious diversity within a framework of inclusion and tolerance.

In particular, Article 130 (today, Principle of Separation of State and churches) allowed the churches and religious communities to acquire legal personality once they obtained their registration as religious associations by the Ministry of Interior.

Now, the last constitutional reform to Article 24 on July 19, 2013, implied the substitution of the expression "every man" for "every person," the introduction of the right to freedom of ethical convictions, conscience, and religion. It makes clear that this freedom includes the right to participate individually or collectively, both in

\footnotetext{
${ }^{1}$ It is worth noting that the concept of "Mexican ecclesiastical law" is formally limited, because it refers to the ecclesiastical, to the institutional, to the churches, but not all religious communities are erected in this way, as churches; for example, the case of Jewish, Buddhist, Hindu communities. For that reason, among others, I prefer to refer to the "Mexican Law of Religion" as the set of rules of the State concerning the religious factor that attends to the religious needs and interests at the individual level (individual juridical person), corporate level (religious communities and religious associations), and collective level (indigenous peoples, with respect to their religious practices and customs), under the principles of religious freedom, laicity (laicidad), and separation of state and churches (or religious communities). Under Mexican law of religion is to be understood the "totality of state juridical norms, which regulate the religious factor related to religious needs and interests of its holders at the individual level, the corporative level (religious communities and religious associations) and the collective level (indigenous people, in the case of their religious usages and customs), and under the fundamental principles: laicity of the State, religious freedom and separation between State and religious communities" (Medina González 2005).
} 
public and in private, in ceremonies, devotions or acts of worship, provided they do not constitute an offense punishable by law. Although a prohibition is incorporated: "No one can use the public acts of expression of this freedom for political purposes, proselytism or propaganda."

Before this reform, several civil and non-Catholic religious associations demonstrated in about 20 states in the Mexican Republic to warn that they would not allow the reform of Article 24 of the Constitution, because it threatens the secular nature of the Mexican State and it gives privileges for Catholics. They expressed three arguments: (I) The intention of the reform is the dismantling of the secular state. It is intended to use it to demand clerical privileges: mainly replacement of secular education for religious instruction in public schools and control of mass media. (II) The handling of the reform in the concept of "freedom of religion." The redefinition of "freedom of religion" that the Catholic hierarchy seeks to establish offers a tendentious and biased concept of that freedom to provide religious education in public schools as a religious privilege. (III) The consequences of reform are an affectation of the freedoms of religious minorities. For example, religious education in public schools will cause that children and adolescents who profess a different faith then Catholic become victims of acts of intolerance and discrimination. Religion is also represented as a factor of division among students professing different faiths and as an element of social polarization that will damage seriously the living together.

On the other side, the constitutional reform to Article 40 on November 30, 2012, to include the "lay character" of State was not really necessary to know that "laicity" is the scenario and presuppose for the effective exercise of fundamental freedoms. Laicity and religious freedom are not opposed and are not mutually excluded. Reference to an "open laicity," "positive laicity," or even "healthy laicity" is made. For example, religious freedom includes the teaching of religion too, and the state has to guarantee it. The current dimension of laicity is particularly in the field of cultural identities and protection of minorities. The issue of laicity is not only "political" but also related to the "minorities," who defend their "vulnerability." The concept of the secular (lay = laico) state is dynamic, and is linked to social processes. In the debate on laicity are present new actors, and not only the traditional State-church or churches but also women, academics, homosexuals, and indigenous people. Certainly, the "pathology" of laicity would be to reduce religion to the private sphere alone. The formula "for greater religious freedom" less "lay state" is a fallacy.

However, the exercise of religious freedom recognizes limits.

There is no doubt that the "recent" constitutional reforms involve two key elements of the rule of law (Estado de derecho): (I) Popular sovereignty, under Article 40 of the Constitution (linked to Article 39). (II) Human rights, including the right to religious freedom established in Article 24 of the Constitution.

For the following analysis, I will focus my remarks on four fundamental aspects: binomial "Law and Religion"; analysis of the amendments to Articles 24 and 40 of the Constitution; approaches to public policy management of religious diversity; and cases. 


\section{Law and Religion}

This conceptual binomial gives me the opportunity to analyze the amendments to Articles 24 and 40 and their constitutional implications, from the perspective of the Mexican Law of Religion, whose core is religious freedom, and it grounds the dignity of the human person, so that I will not focus only in the so-called "churchState relations," which at least in its formal name apparently may be restrictive and not open to religious communities that are not churches. ${ }^{2}$

Here, I want to refer to the important intervention of François Houtart in the Assembly of the United Nations in $2008,{ }^{3}$ which noted that the world needs alternatives and not merely regulations, since it is not sufficient to rehabilitate or maintain a system but to transform it.

It is a question of permitting all forms of knowledge, including traditional forms of all philosophies and cultures, to participate in the construction of alternatives " "in breaking the monopoly of Westernization." This author considers various aspects among religions:

the wisdom of Hinduism in relationship to nature, the compassion of Buddhism in human relations, the permanent quest for utopia in Judaism, the thirst for justice which defines the prophetic current in Islam, the emancipatory power of the theology of liberation in Christianity, the respect for the sources of life in the concept of the land itself among the indigenous peoples of the Americas, the sense of solidarity expressed in the religions of Africa, can all make important contributions in the context of mutual tolerance guaranteed by the impartiality of political society.

This consideration has its own specific weight to the topic at hand, since to democratize society within a framework of laicity (laicidad) is to allow multiculturalism to be expressed through religious freedom. A lay (laico) State that renounces religious freedom, renounces the claim of this human right in all its dimensions; it loses its right to exist as such, i.e., as a lay (laico) State.

\section{Analysis of the Amendments to Articles 24 and 40 of the Mexican Constitution}

This second aspect focuses primarily on distinguishing between the justification for the existence of the constitutional reform to Article 24 of January 28, 1992, and

\footnotetext{
${ }^{2}$ I mean Jewish, Buddhist and Islamic religious communities.

${ }^{3}$ Cf. General Assembly of the United Nations. Panel on the financial crisis, October 30, 2008.

${ }^{4}$ Here, I want to refer to an indigenous representative Chamula, expert in Tsotsil, indigenous language of the National Commission for the Development of Indigenous Peoples, who-in December 2010 — questioned the application of human rights in indigenous communities, since in these-he says- "there is no freedom but complementarity, there is no equality but reciprocity, there is no fraternity but relatedness." How to translate the Universal Declaration of Human Rights into the indigenous context? It is a challenge for the indigenous peoples themselves.
} 
the reason for the existence of the recent amendments to Articles 24 and 40 of the Constitution. $^{5}$

Regardless of the political nature attributed to the constitutional reforms of January 28, 1992, about a "search for legitimacy of the Federal Executive," it was rather to combat obvious anachronism and open simulation with:

(a) The adequacy of the rules in religious matters to social reality, to prevent thereby any simulation;

(b) The updating of the regulations on religious freedom. It demands that the Mexican government complies with international treaties signed by the Mexican state to ensure that fundamental right; and

(c) The need to promote, in the awareness of Mexican society, respect for the legal system and proper implementation of the law on religious matters.

With this constitutional reform and the subsequent issuance of the Law on Religious Associations and Public Worship (July 15, 1992), several processes took place:

(a) The construction of laicity (laicidad) on the recognition of religious diversity.

(b) The visibility of religious minorities, which may be registered as religious associations before the Ministry of Interior to obtain juridical personality. ${ }^{6}$

(c) The recognition of religious diversity that creates conditions for inclusion and tolerance that are essential for peaceful coexistence among different believers, religious communities, and religious associations.

\subsection{Amendment to Article 40 of the Constitution}

Article 40, in close connection with Article 39 of the Mexican Constitution, ${ }^{7}$ establishes the fundamental characteristics adopted by the political organization of the Mexican people.

\footnotetext{
${ }^{5}$ Amendments to Articles 24 and 40 of the Mexican Constitution were approved by the Senate on March 28, 2012. The amendment to the first paragraph of Article 24 received 72 votes in favor and 35 votes against; while the amendment to Article 40 was approved by 97 votes in favor, 3 against, and one abstention. The amendment to the first paragraph of Article 24 of the Mexican Constitution was published on July 19, 2013, in the DiarioOficial de la Federación. The amendment to Article 40 of the Mexican Constitution was published on November 30, 2012, in the DiarioOficial de la Federación.

${ }^{6}$ In the year 1992, were registered as religious associations only three communities of Catholic orientation (the Catholic, Apostolic, and Roman Church in Mexico, the Mexican Episcopal Conference, and the Primatial Archdiocese of Mexico); in 1993 and 1994 were registered diverse religious associations, mostly, different than Catholic.

7“Article 39. National sovereignty is vested essentially and originally in the people. All public power derives from the people and is instituted for their benefit. The people have at all time the inalienable right to alter or amend their form of government".
} 
One reason, apparently, "to raise the lay (laica) nature of the State to constitutional rank" "was the reaction to assumed acts that "violated" this lay nature (for example: to allow religious services at public hospitals $;{ }^{9}$ to deny minority rights; to impose the beliefs of the majority; ${ }^{10}$ and to dictate public policies based on religious criteria for 110 or 120 million Mexicans as if they were Catholics). ${ }^{11}$

Generally, in the case of the amendment to Article 40 of the Constitution, it was argued that this reform was made to ratify, to reaffirm the lay (laica) nature of the Mexican State, even to defend, and strengthen it against the backward and obscurantist temptation, ${ }^{12}$ and against attacks on laicity (laicidad), and that "postponing the fullness of secularity of the State" means the "risk of a successful [attack] from the rhetoric of intransigence." 13

In sum, this constitutional reform was rather "confirmatory," "declarative," and not "foundational" or "constitutive" in character. Therefore, even if there had not been any constitutional reform to Article 40, the laicity (laicidad) of the Mexican state would have remained intact. ${ }^{14}$

\footnotetext{
${ }^{8}$ And here I want to ask: was the Mexican state not lay (laico) already? And if this is so, then the article 3 of the Law of Religious Associations and Public Worship, which establishes "The Mexican state is lay (laico)," was unconstitutional.

9“'Deplora el Senado que el carácter laico del Estado haya sido vulnerado," La Jornada, February 18,2010 , p. 10.

10“Intelectuales piden a senadores ratificar el carácter laico del Estado mexicano," Carlos Monsiváis censura cerrazón de la derecha, La Jornada, February 19, 2010, p. 10.

11 "Censuran a Rivera por su postura sobre el Estado laico," Rumbo de México, February 19, 2010.

${ }^{12}$ See Footnote 11.

${ }^{13}$ Cf. "Navarrete confía en que el Senado apruebe reforma para Estadolaico," La Crónica, February 19, 2010 , p. 9.

${ }^{14}$ The Mexican state is lay (laico), not confessional, and does not subscribe to any religion or religious denomination as its own. The conception of a lay (laico) State is dynamic, also linked to social processes.

Precisely, one of the dimensions of laicity (laicidad) is in the field of cultural identities and the defense of minorities, of course in attention to the following guiding principles: (1) religious freedom. (2) Separation of State and churches (or rather, religious communities). (3) No intervention by the authorities in the internal affairs of religious associations (linked to respect for the right of self-determination of religious communities). (4) Authorities may not attend in an official character any religious act of public worship. (5) Churches and other religious communities should not interfere in the functions of the state. (6) State laicity (laicidad). On November 6, 2012, the Senate declared approved the amendment of Article 40 of the Constitution, establishing formally the lay (laica) nature of the Mexican State, as follows: "Article 40. It is the will of the Mexican people to constitute a representative, democratic, lay (laica), and federal Republic composed by States, free and sovereign in all matters concerning their internal affairs; but united in a federation established according to principles of this fundamental law." (The underlined is mine). This can be assumed to be a platform to strengthen the management of religious diversity.
} 
Here, I would refer comparatively, while maintaining a proper sense of proportion, the case of the German law of religion, where, although there is no principle of laicity (laicidad), there is the principle of neutrality. The Fundamental Law of the Federal Republic of Germany does not explicitly contain the word "neutral," this nature of the German State has been recognized and developed by the jurisprudence of the Federal Constitutional Court. ${ }^{15}$

In my opinion, the "laicity" is a scenario, which may be presupposed, where the effective exercise of fundamental freedoms - including the freedom of religiontakes place. ${ }^{16}$ Therefore, "laicity" and "religious freedom" are not opposed and are not mutually excluded, since a lay (laico) state must ensure full enjoyment of religious freedom.

Certain documents such as the Universal Declaration of Laicity (laicidad) of XXI Century ${ }^{17}$ and the Lay (laica) Charter $^{18}$ do not address in its true size, at least explicitly, religious freedom; rather, they include it only by reference, for example, this is related to "freedom to adhere to a religion", "free choice in matters of religion" and the "right to profess or not to profess religious beliefs." The "Alphabet of the lay (laica) Republic"19 simply refers to "freedom of worship" or "to exercise any religious option or not practice any one." But it is evident that religious freedom in its complexity implies this and much more.

\footnotetext{
${ }^{15}$ From the freedom of belief, Article 4, paragraph 1 of the Fundamental Law, derives the principle of neutrality towards different religions and confessions. The ideological-religious neutrality is a binding mandate for the State. The State's obligation to neutrality implies that the State must conduct itself equally before various religious orientations; the State cannot generate religious indifferentism. The State is prohibited from favoring certain denominations, also from making distinctions between religious communities and valuing the belief or non-belief of its citizens, and noting their convictions as correct or false. Cf. BverfGE 24, 236 (246), BVerGE 32, 98 (106), BVerfGE 33, 23 (28), BVerfGE 93, 1 (16).

16 "Pathology" of the laicity (laicidad) is to reduce religion to the private sphere.

${ }^{17}$ See Libertades laicas. Red Iberoamericana por las Libertades Laicas. Programa Interdisciplinario de Estudios sobre las Religiones. El Colegio Mexiquense, A.C.

${ }^{18}$ Cf. Extraordinary Chair "Benito Juárez" of UNAM, January 14, 2013.

${ }^{19}$ José Woldenberg, ex-counselor of the Federal Electoral Institute introduced this alphabet during the Forum „Laicidad y democracia: 150 aniversario de la libertad de pensamiento.”
} 


\subsection{Amendment to Article 24 of the Constitution (Freedom of Religion or Belief)}

\begin{tabular}{|c|c|}
\hline $\begin{array}{l}\text { Article } 24 \text { by decree published on January } 28, \\
1992\end{array}$ & $\begin{array}{l}\text { First paragraph amended by decree published } \\
\text { on July } 19,2013\end{array}$ \\
\hline $\begin{array}{l}\text { Article } 24 \text {. Everyone is free to embrace the } \\
\text { religion of his choice and to practice all } \\
\text { ceremonies, devotions, or observances of his } \\
\text { respective faith, either in places of public } \\
\text { worship or at home, provided they do not } \\
\text { constitute an offense punishable by law } \\
\text { The congress cannot dictate laws that } \\
\text { establish or prohibit any religion } \\
\text { Every religious act of public worship must be } \\
\text { performed strictly inside places of public } \\
\text { worship, which shall at all times be under } \\
\text { governmental supervision }\end{array}$ & $\begin{array}{l}\text { Article } 24 \text {. Every person has the right to } \\
\text { freedom of ethical convictions, conscience } \\
\text { and religion, and having or taking, as the case } \\
\text { may be, whichever they like. This freedom } \\
\text { includes the right to participate, individually } \\
\text { or collectively, both in public and in private at } \\
\text { ceremonies, dedications or acts of worship, as } \\
\text { long as they are not a crime or transgression } \\
\text { penalized by the law. Nobody can use public } \\
\text { expression acts of this freedom with political } \\
\text { purposes, proselytism or political propaganda }\end{array}$ \\
\hline
\end{tabular}

\subsubsection{An Approach to the Three Argued Reasons for Rejecting the Amendment to Article 24 of the Constitution}

There were several groups, ${ }^{20}$ which expressed different reasons for rejecting the amendment to Article 24 of the Constitution and these were linked to ${ }^{21}$ :

(a) The intent of reform. It was argued that this was "the dismantling of the lay (laico) State".

(b) The manipulation of reform. It was argued that redefining "freedom of religion" was offering a tendentious and biased concept of that freedom.

(c) The consequences of reform. There was reference, in this respect, to the effect on the freedoms of religious minorities.

\footnotetext{
${ }^{20} \mathrm{~A}$ large majority was evangelical groups, as shown by the various demonstrations that occurred in more than 20 states of the Mexican Republic.

${ }^{21}$ Approximately, 50 organizations and associations publicly opposed the amendment to Article 24, among which are Pentecostal churches, the Light of the World, Apostolic Church of Mexico, Presbyterian churches, and Masonic Grand Lodge. Moreover, it was expressed that some small religious groups are in opposition to this reform, because they considered that the reform would benefit the Catholic associations. Historic churches—such as the latter-and Jewish, Orthodox, Anglican or traditional evangelical churches supported the amendment to Article 24.
} 
It was noted that reference to the supposed "danger" of religious teaching in public schools was common in these three reasons.

The reference to religious freedom only as "teaching religion in public schools" represented, rather than a serious approach to the dimensions or areas of religious freedom, a manipulation of the discourse on religious freedom that prevented a serious analysis of its real scope.

\subsubsection{Analysis of Article 24 of the Constitution}

The Article 24 in force provides that:

Every person has the right to freedom of ethical convictions, conscience and religion, and having or taking, as the case may be, whichever they like. This freedom includes the right to participate individually or collectively, in public or private, in the ceremonies, devotions and acts of worship, provided they do not constitute a crime or an offense punishable by law. No one may use the public acts of expression of this freedom for political purposes, proselytism or propaganda. ${ }^{22}$

Although the new version of this Article uses an inadequate legislative technique, the substance of the constitutional reform of Article 24 focuses on: (1) Replacement of "every man" by "every person" in accordance with the terminology adopted by all international instruments on human rights. (2) The formal introduction of the right to freedom of ethical convictions.

(a) freedom of ethical convictions. Its inclusion-it seems to me-was linked mutatis mutandis to a formulation used in Article 4 of the Fundamental Law of the Federal Republic of Germany, which refers to the profession of religious and ideological beliefs (or non-religious worldview) called Weltanschauung, ${ }^{23}$ whose translation into Spanish is complex, but in the case of Article 24 was adopted simply as "ethical convictions," which creates some confusion especially when this is disassociated from the "freedom of religion."

\footnotetext{
${ }^{22}$ The text of Article 24 of the Constitutional Reform from January 28, 1992, establishes: "Every man is free to embrace the religion of his choice and to practice the ceremonies, devotions and acts of worship, provided they do not constitute a crime or an offense punishable by the Law" (first paragraph). "The Congress of the Union may not enact laws establishing or prohibiting any religion" (second paragraph). "Religious acts of public worship must regularly be performed inside the temples. Those extraordinarily performed outside of them shall be subject to the Law" (third paragraph).

23“Art und Weise, wie jemand die Welt und ihren Sinn sowie sein Dasein betrachtet und beurteilt" (Mode and form how someone observes and judges the world, its reason and its existence), (Wahrig 1997). Gerhard Anschütz considers Weltanschauung as the doctrine comprising the total and universal world that seeks to recognize and to value the position of man in the world.
} 
(b) freedom of conscience. ${ }^{24}$ Various international instruments establish, unanimously, freedom of conscience as a fundamental right, where "consciousness" is precisely its subject.

Note that within the elements of freedom of conscience are: (1) "Freedom of formation of consciousness" as the right guaranteed to every person to follow his own representations in the formation of concepts of religious-moral value or disvalue without any influence of State coercion or social pressure, and perform this purpose under the constitutional legal order (Listl and Dietrich 1994) (2) "Freedom of realization of consciousness" implies "to omit" the legal prescribed behavior and "not to observe" the legally established rules of "not to do." It is here that the "right of conscientious objection" is linked with the fundamental right to "freedom of conscience."

The International Covenant on Civil and Political Rights does not explicitly refer to a right of conscientious objection, however, in General Comment No. 22 to Article 18 of the Covenant, it considers that such right can be derived precisely from Article 18, paragraph 1, and there shall be no differentiation among conscientious objectors on the basis of the nature of their particular beliefs.

At the bottom of the issue about conscientious objection, ${ }^{25}$ there is a relationship of tension between constitutional freedom and equality. ${ }^{26}$

Of course, freedom of conscience does not exclude or exempt, without further ado, the objector, of having to fulfill civic obligations, because a person who is recognized as a conscientious objector must perform, in principle, an alternative service (servicio sustitutorio), in order to reconcile precisely the right to freedom of conscience with the observance of common duties for all within the rule of law.

The Mexican Law of Religion provides what one might describe as "conscientious objection secundum legem," for example, that the legislation itself establishes a certain "right to object" to justify the breach of a legal mandate. ${ }^{27}$

\footnotetext{
${ }^{24}$ While it is true that the Constitution of the United Mexican States did not establish expressly the freedom of conscience, this was considered by the Constituent Assembly of 1856-1857 in the sense that freedom of conscience, based on the most intimate convictions of the person, could not be subject to regulation by the State legal order. Meanwhile, the Constituent of 1916-1917 considered freedom of conscience as presupposed and included in Article 24 of the Constitution, since, in the opinion of the liberals of the period, Article 24 expressed, on the one hand, a large freedom of conscience and, on the other hand, limitation only for religious acts which constitute a crime or an offense punishable by law.

25 "Conscientious objection" comes to be defined as "the attitude of a person who refuses to comply with a rule of law under a binding mandate from his consciousness, which is in radical opposition to the implicit ethical content of the legal norm. See Lima Torrado, Jesús. Desobediencia civil y objeción de conciencia, Mexico, Comisión Nacional de los Derechos Humanos, 2000, p. 25.

${ }^{26}$ See Die Rechtsstellung des Wehrdienstverweigerers aus Gewissensgründen in den Mitgliedsstaaten des Europarats, Ein vergleichender Überblick, Max-Planck-Institut für ausländisches Recht und Völkerrecht, 1967, p. 231.

${ }^{27}$ For example, this is the case of Article 10 of the Military Service Law (Ley del ServicioMilitar) and Article 38, paragraph III of its Regulation (Reglamento) concerning the ministers of worship, who may be exempted from compulsory military service; also this is the hypothesis in the case of
} 
In addition, it is essential to examine carefully the second paragraph of Article 1 of the Law of Religious Associations and Public Worship, ${ }^{28}$ in order to align its content with the current Article 24 of the Constitution, which expressly guarantees freedom of conscience.

(c) freedom of religion. Notwithstanding the constitutional reform on human rights from June 10, 2011 (the rules on human rights shall be interpreted in accordance with the Constitution and international treaties on this matter, favoring to the people all the time the more extensive protection), and in addition to the requirements of the New Law of Amparo, ${ }^{29}$ (the sphere of protection of rights is extended, the human rights established within international treaties are subject of direct protection) still, the reform of Article 24 reinforces full religious freedom, from the interpretation of this in international instruments and from the contributions of comparative law.

Religious freedom consists of an internum forum and an externum forum.

The internum forum relates to the freedom of belief. "Positive freedom of belief," i.e., to have or to adopt ${ }^{30}$ a belief of one's choice "or preference" (International Covenant on Civil and Political Rights) as well as to maintain or to "change his belief" 31 (American Convention on Human Rights); this internum forum includes the "negative freedom of belief," which is summarized in not having any belief.

The forum externum relates to the "freedom to profess a belief." "Positive freedom of profession" involves the right to say what one believes, which includes the freedom to propagate one's belief, and also the freedom of dispreading other beliefs (what is known as a missionary activity) and to say that one does not believe at all.

"The negative freedom of profession" guarantees the right to keep what one believes secret, or the right to silence (Schweigerechtin German law of religion).

Moreover, the freedom of exercise of religion in any form involves exercising it alone, in a community, in private (for example, the called devotio domestica simplex-private devotion without the intervention of a minister of worship of one's religious confession - and devotio domestica qualificata - private devotion involving a minister of worship of one's religious confession), and in public (the called exercitium religionis publicum) (Listl and Dietrich 1994).

\footnotetext{
Article 59, Health Law for the Federal District, where it is provided that doctors, for reasons of a religious nature, may refuse to perform an abortion.

${ }^{28}$ This establishes: "Religious convictions do not exempt in any case from complying with laws of the country. No one may invoke religious motives to evade the responsibilities and obligations established in the laws."

${ }^{29}$ Published on April 2, 2013, in the Diario Oficial de la Federación.

${ }^{30}$ The "freedom to adopt a belief" consists usually in search of a community of believers, learn about it, and take its doctrine.

${ }^{31}$ The "freedom to change one's religion" implies in the background "the right to abandon or to resign from being a member from a community of believers and to enter another." This formulation has been considered in many cases instead of "to change one's religion" because it has been objected usually by Islamic countries, such as Saudi Arabia. See Nowak (1989).
} 
Moreover, the manifestations of the exercise of religion include, for example (Listl and Dietrich 1994), Religious service: as the typical form of religious adoration or proclamation, for example, worship. Religious uses: among which are processions, wearing/carrying of religious clothing or (a certain style of) beard, circumcision, prayers, tolling of bells, flying of church banners; in short, rites and rituals of different religions. Praxis (practice): conducting religious assemblies, foundation and support of charities and humanitarian institutions; manufacture or acquisition of ritual objects; collecting donations; training of religious leaders; observance of days of rest and specific holidays; missionary activity; sustaining religious hospitals; implementation of development projects; distribution of flyers; pacifists, motivated by a pacifist spirit. Teaching: transmission of content from one religion or worldview in religious schools, in public schools, in various forms of non-formal education and in missionary work.

Also freedom of religious association is part of the fundamental right of religious freedom in its positive and negative aspect.

In this regard, religious freedom in Mexico should not be a taboo subject. Hence, the importance of serious and open debate on issues such as: the right to selfdetermination of religious communities, as well as freedom of expression of their ministers of worship; mass media in the ownership or possession of religious associations; the right of parents to ensure the religious and moral education of their children in conformity with their own convictions, even in public schools; the protection of cultural property of a religious character; and, attention to the problems of displaced indigenous people because of "religious intolerance."

It clarifies that this freedom includes the right to participate individually or collectively, in public or private, in ceremonies, devotions, or acts of respective worship, provided they do not constitute a crime or an offense punishable by law.

In this respect, it is not that "this freedom includes the right ...", but rather "this right includes freedom ..." (in accordance with Article 18 of the International Covenant on Civil and Political Rights, ${ }^{32}$ and Article 12 of the American Convention on Human Rights ${ }^{33}$ ). In addition to the observation about the inadequate legislative technique used, it is considered that such provision falls far short in scope, at least formally, when it refers only to ceremonies, devotions and acts of respective worship.

Finally, a prohibition is incorporated: no one can use the public acts of expression of this freedom for political purposes, proselytism or propaganda. The questions are: who is the addressee of this? Any person? What specifically does "using public acts of expression of this freedom" mean? What does "this freedom" mean?

\footnotetext{
${ }^{32}$ Article 18 of the Covenant: (1) "Everyone shall have the right to freedom of thought, conscience and religion. This right shall include freedom to have or to adopt a religion or belief of his choice, and freedom, either individually or in community with others and in public or private, to manifest his religion or belief in worship, observance, practice and teaching."

${ }^{33}$ Article 12 of the Convention: "Everyone has the right to freedom of conscience and of religion. This right includes freedom to maintain or to change one's religion or beliefs, and freedom to profess or disseminate one's religion or beliefs, either individually or together with others, in public or in private."
} 
The "freedom of ethical convictions, conscience and religion" or the "freedom to participate individually or collectively, in public or private, in ceremonies, devotions, or acts of respective worship"? Is this prohibition is applicable during an electoral campaign and also in non-election times? What would be the sanction for contravening this provision?

By reading this provision, suddenly came to my mind the image of the presidential candidates who gathered at the Mass celebrated by Pope Benedict XVI in Silao Guanajuato in 2012, ${ }^{34}$ where some of them even took communion publicly.

President Enrique Peña Nieto also received communion at the Mass celebrated by Pope Francisco on February 12, 2016, at the Basilica of Guadalupe during his visit to Mexico. ${ }^{35}$

If at the time a prohibitive provision like this had been in force, would this prohibition have been applicable to presidential candidates or why could it not be applicable to the president of Mexico?

Moreover, prohibitions against ministers of worship engaging in politics matters existed before, for example, to hold public offices and not be elected for public offices, ${ }^{36}$ those who have ceased being ministers of worship with anticipation and in the manner established by law, may be elected (Article 130 of the Constitution d) and Article 14, first paragraph, LARCP); to associate for political purposes, to proselytize in favor of or against any political candidate, party or association (Article 130 of the Constitution, and Articles 12 and 29 LARCP); to celebrate political meetings in temples (Article 130 of the Constitution and Article 21 LARCP); in developing public acts of their own ministry, to induce the electorate to vote or not to vote for a particular candidate or political party (Article $404 \mathrm{CPF}$ ).

To these, it has been added: "no one can use the public acts of expression of this freedom for political purposes, proselytism or propaganda" as a "burden" additional to the bans for ministers of worship, especially if this prohibitive requirement seems an "openletter" to the exercise of discretional activity of governmental authorities in its application.

\section{Public Policies for Managing Religious Diversity}

The laicity (laicidad) of the State, as a scenario and presupposed, where the effective exercise of religious freedom and other fundamental freedoms occurs, also

\footnotetext{
${ }^{34}$ Papal Mass held on March 23, 2012, at Bicentennial Park in Silao, Guanajuato.

${ }^{35}$ See https://www.sdpnoticias.com/nacional/2016/02/13/comulgo-pena-nieto-en-misa-de-elpapa-en-la-basilica and http://www.animalpolitico.com/2016/02/los-politicos-de-mexico-enprimera-fila-para-ver-al-papa-francisco/.

${ }^{36}$ In the doctrine, it is discussed the legal nature of this constitutional impediment of the ministers of worship to exercise a passive vote, placing it within three possible explanations: (1) An incompatibility on the basis of the principle of State-churches separation. (2) A mutilation of human rights of ministers of worship, or (3) A discriminatory treatment.
} 
involves the generation of appropriate public policies for the management of religious diversity.

At the legislative level, it is necessary to legislate without discrimination, as happened with the derogation of the word "sect" in federal regulations. This word was removed from the Federal Code of Electoral Institutions and Procedures (COFIPE) ${ }^{37}$ but this has not been done in case of the Federal Civil Code, because Article 1330 still includes the word "sect". 38

Moreover, the National Council to Prevent Discrimination (CONAPRED) published a Handbook for lawmaking without discrimination, which will undoubtedly contribute to that purpose.

At the jurisdictional level, the interpretation of "religious freedom and their different facets" 39 and "differences of religious freedom and freedom of worship" 40 is developed.

At the federal executive level, it is necessary to comply with the generation of an appropriate public policy of management of religious diversity.

Among the public policies for management of religious diversity are the following.

\subsection{Political-Administrative Attention for the Transformation}

Regardless of the circumstances that involved a significant shift of the administrative body of the federal executive in charge of religious affairs before 1992, it was called "Underdirectorate of Religious Worship, Firearms and Explosives"; and with the reform from January 28, 1992, the situation changed toward the formation of a

\footnotetext{
${ }^{37}$ The COFIPE was abrogated and the General Law of Electoral Institutions and Procedures (LGIPE) came into force, which does not contain the term sect. The LGIPE was published on May 23, 2014 in Diario Oficial de la Federación.

${ }^{38} \mathrm{It}$ is recommended to carry out this derogation also in local regulations (electoral codes and civil codes), where the word "sect" is present.

39،Libertad religiosa. Sus diferentes facetas," in Semanario Judicial de la Federación, NinthEpoch, FirstChamber, Thesis 1a. LX/2007, Subject: Constitutional, isolated thesis, February 2007. "Freedom of worship" means "freedom to practice the ceremonies, rites and meetings associated with the cultivation of certain religious beliefs."

40 "Libertad religiosa y libertad de culto. Sus diferencias," in Semanario Judicial de la Federación y su Gaceta, NinthEpoch, FirstChamber, Thesis 1a LXI/2007, Subject: Constitutional, isolatedthesis, February 2007. "Acts of public worship" as "the acts specifically oriented to develop collectively rites, ceremonies and practices of different religions recognized as institutionalized or formalized expressions of religious faith, defined and governed by pre-established rules by them."
} 


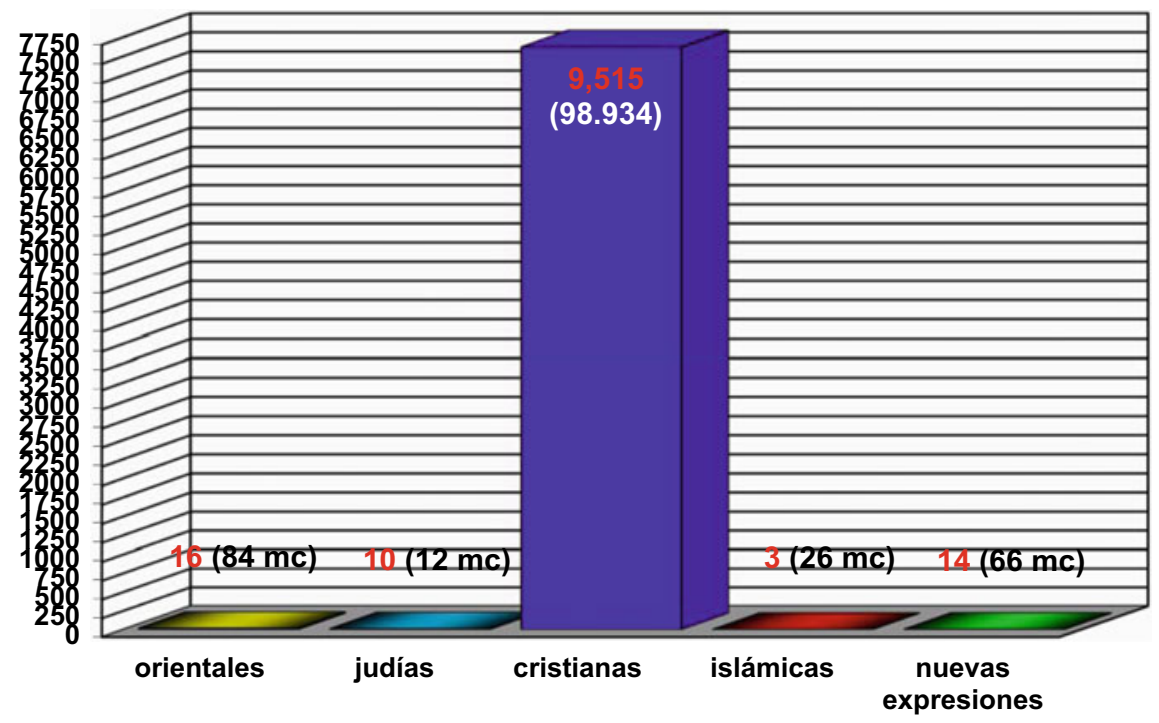

Fig. 1 Registered religious associations (9.558) and ministers of worship (ministros de culto $=$ mc, 99.122) (April 31, 2020)

General Directorate of Religious Associations, within an "Undersecretariat for Population, Migration and Religious Affairs" and today an "Undersecretariat of Democratic Development, social participation and religious affairs." Here, it is expedient to review the vision, mission and objectives of this Undersecretariat (Fig. 1).

While the services offered by the General Directorate of Religious Associations formally involve administrative attention to religious diversity, this is only part of public management policy (Table 1). ${ }^{41}$

Since the last administration took office on December 1, 2012 an the new administration on December 1, 2019, a rethinking of public policy for the management of religious diversity under the last National Development Plan 2013-2018 and today under the National Development Plan 2019-2024 is expected, and depending mainly on the implementation of the constitutional reform of Article 24.

Finally, the Law of Religious Associations and Public Worship has had important reforms:

\footnotetext{
${ }^{41}$ The management of the Federal Executive relations with religious associations (churches and religious communities), with full respect for the lay (laico) spirit of public institutions, formally has had as guidelines: (a) Improving the relationship with religious communities, religious associations and religious traditions existing in the country; (b) Greater openness and fairness for different religions; (c) Assumption of a positioning of "non-control" by the authority on religious associations; (d) Respect of the internal life of religious associations and religious pluralism; (e) Strengthening of interfaith dialogue and coexistence; (f) Permanent dialogue with religious organizations and ministers of worship; (g) Transparency and access to information on religious matters; (h) Improving the administrative service to attend the religious associations; (i) Application of modern technology for recording and processing information in religious matters.
} 


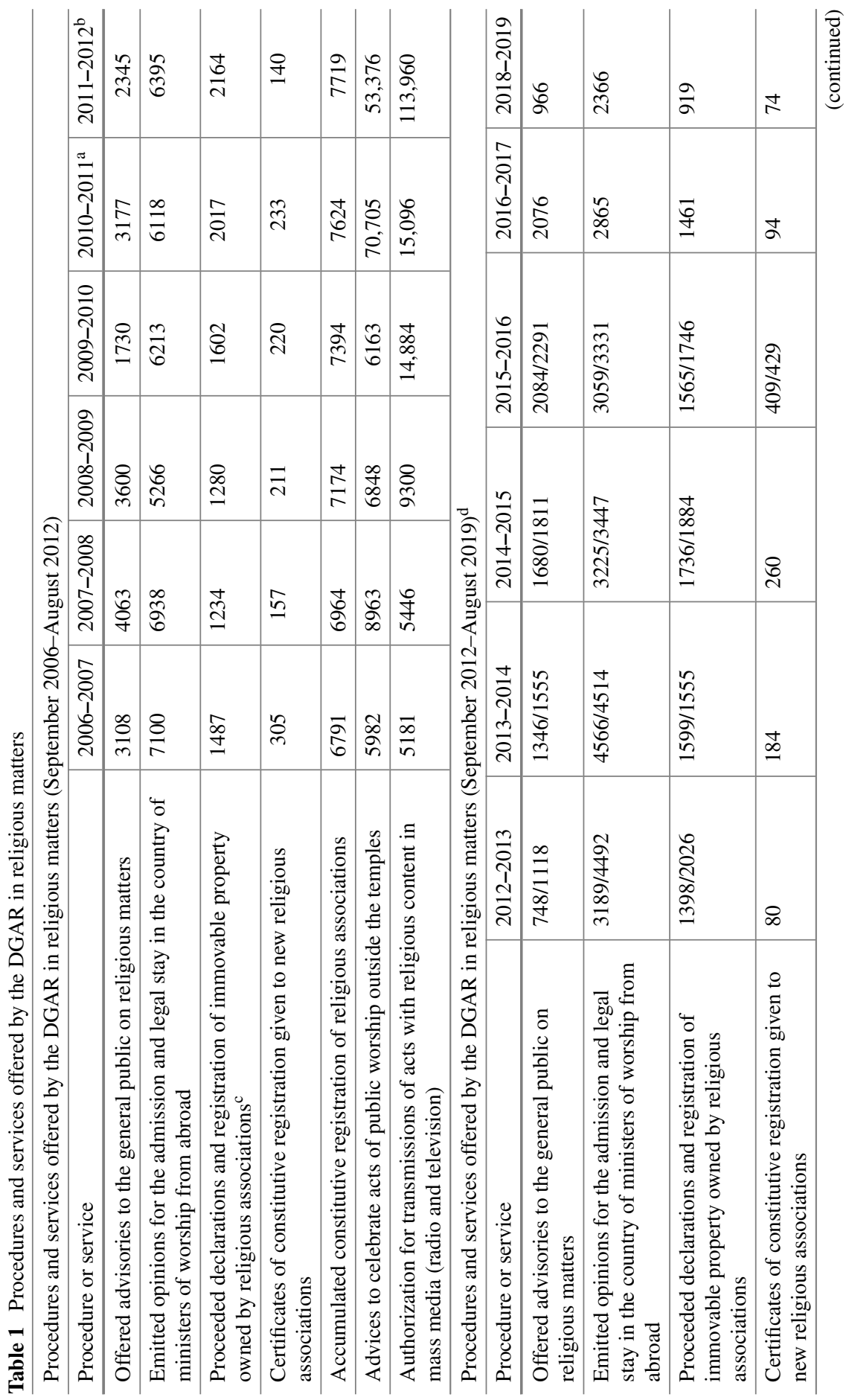




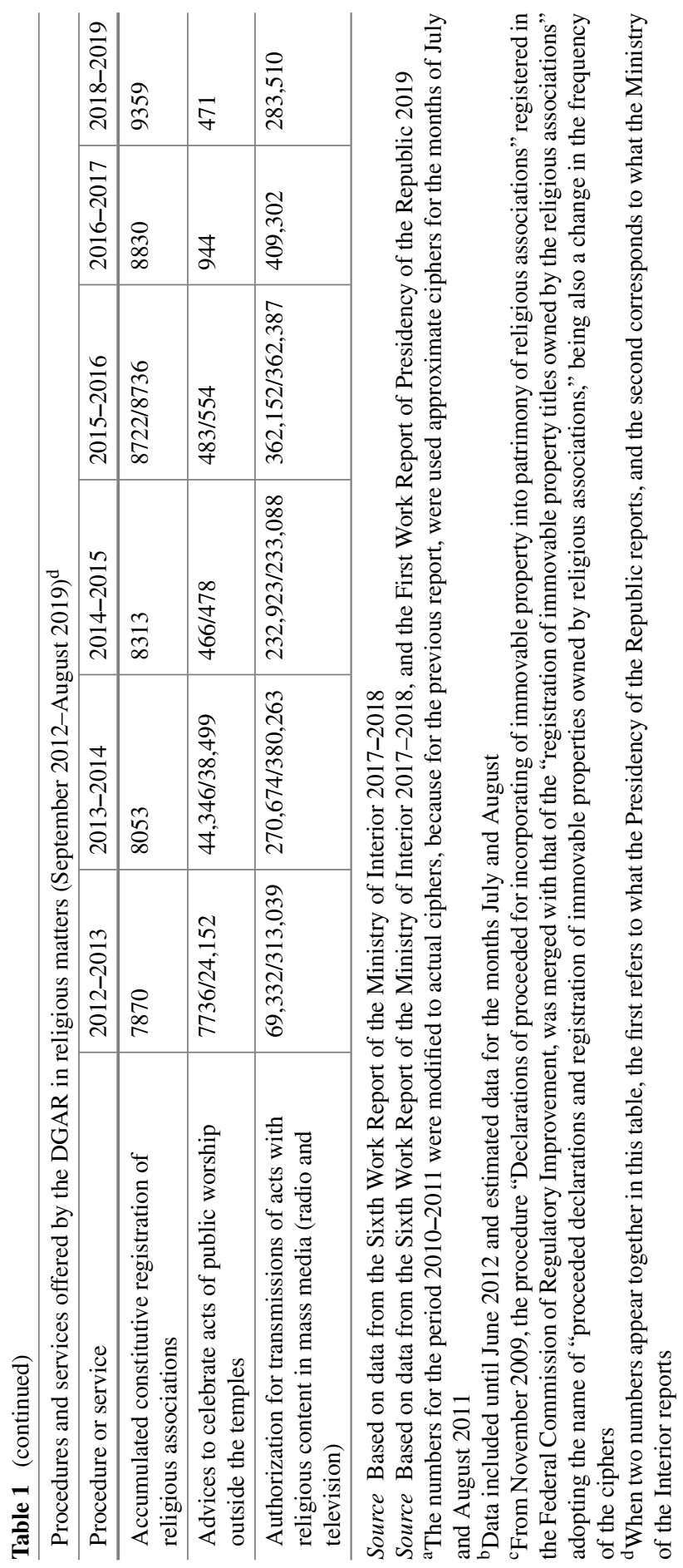


(a) April 24, 2006, to incorporate dialogue and tolerance as an obligation of religious associations (Article 8, fraction III).

(b) August 19, 2010, to include full respect for human rights (Article 3, first paragraph, article 8th, fraction IV) and the protection of children and adolescents (article 12 Bis, Article 29 fractions XII and XIII, Article 31 fraction V).

(c) May 25, 2011, on the immigration status of religious ministers (Article 13).

(d) December 17, 2015, to incorporate the Ministry of Culture instead of the National Council for Culture and the Arts (CONACULTA) (Article 20 first paragraph), before which it will register those responsible for the temples, property of the nation.

\subsection{Extraordinarily Acts of Public Worship Are not "Public Spectacles"}

It must be insisted that in the case of holding acts of extraordinarily public worship of religious associations, provisions that strictly correspond to "public performances" 42 should not be applied since it is not possible to fulfill the same requirements for implementation and because "extraordinarily acts of public worship" are not "public spectacles."

\subsection{Spiritual Assistance}

It is required further to facilitate spiritual support in health, social care, and rehabilitation institutions, making this effectively one of the dimensions of the right to religious freedom of internal people and users. ${ }^{43}$

After the earthquake of September 19, 2017, dioceses, bishops, priests, and lay people attended the emergency in different ways, not only arranging parishes and seminars, as refuge and collection centers, making special collections in the parishes, and channeling everything through Cáritas Nacional (Mexicana) but also offering spiritual accompaniment and psychological attention to the people in need.

For its part, the Central Commission of the Jewish Community of Mexico also helped those affected by the earthquake by establishing collection centers. Churches and religious communities are organized to help the society in the health contingency due to Covid-19. For example, the Mexican Episcopate Conference promotes the "Families without Hunger" campain.

\footnotetext{
${ }^{42} \mathrm{Cf}$. Law for holding public events in the Federal District (Ley para la celebración de espectáculospúblicosen el Distrito Federal), Article 4, V. Public spectacle; Article 25, VII, Requirements of permissions to hold public spectacles.

${ }^{43}$ Based on Article 6 of the Regulation of the Law on Religious Associations and Public Worship, published on November 6, 2003, in the DiarioOficial de la Federación.
} 


\subsection{Prohibition of Discrimination on Religious Grounds}

The constitutional and legal normativity on religious matters assumes the principle of non-discrimination in favor of religious diversity.

Article 1 of the Constitution explicitly prohibits discrimination based on religion and establishes that the authorities have the obligation to promote, protect, and ensure the human rights of all people.

Article 2 of the Law of Religious Associations and Public Worship recognizes the right of individuals to be free from discrimination, coercion or hostility because of their religious beliefs and the prohibition to restrict the exercise of any work or activity for religious reasons.

Article 4 of the Federal Law to Prevent and Eliminate Discrimination prohibits all discriminatory practice. This law establishes the following in Article 9 as discriminatory behaviors: to hinder freedom of religion, religious practices or customs, provided they do not violate public order (paragraph XVI), and to deny religious assistance to persons deprived of liberty, serving in the armed forces or interns in assistance or healthcare institutions (paragraph XVII).

\subsection{Conscientious Objection}

Education authorities have refrained from punishing students-Jehovah's Witnesses-because of their religious beliefs, who refuse to salute the flag and sing the national anthem at civic ceremonies that take place in schools, according to the General Recommendation Nr. 5, issued by the National Commission of Human Rights (May 14, 2003).

However, in the case of basic education teachers, for example, Jehovah's Witnesses are required, in respect of their right to conscientious objection to honoring national symbols, to complying instead of this with an alternative service, so that they should not be separated from their charges - as this happens at the present-because they "do not inculcate love for the country in their students."

\subsection{Coordination Agreements in Religious Matters ${ }^{44}$}

It is necessary to review the status of coordination agreements on religious matters signed by the Ministry of Interior principally with the governments of the states

\footnotetext{
${ }^{44}$ Agreements - that were ready to be signed-are those corresponding to the states of Coahuila, Jalisco, Puebla and Veracruz. Agreements in process of elaboration, in case of the states: Campeche, Guerrero, Queretaro, San Luis Potosi, Sonora, Tamaulipas, Tlaxcala.
} 
of Zacatecas, ${ }^{45}$ Chiapas, ${ }^{46}$ Chihuahua, ${ }^{47}$ Michoacan, ${ }^{48}$ Nuevo Leon ${ }^{49}$ and Quintana Roo, ${ }^{50}$ to update them, and to promote the signing of agreements with the remaining states.

\subsection{Translation of the Law of Religious Associations and Public Worship and Its Regulation into Indigenous Languages}

The Ministry of Interior has promoted the translation of the Law on Religious Associations and Public Worship into various indigenous languages in at least six states. These languages are: Tsotsil, Tseltal, Tojolab'al, Zoque, Cho'l (in Chiapas); Mazahua (in State of Mexico); Náwatl (in Puebla); Náhuatl, Tenek (in San Luis Potosí); Náhuatl, Totonaca (in Veracruz), Purhépecha (in Michoacán) ${ }^{51}$; however, translation of the law by itself is not enough, there should also exist informed knowledge about its content, so this topic must be observed too (Table 2).

Table 2 Translation

\begin{tabular}{l|l}
\hline \multirow{2}{*}{ Federative entity } & Indigenous language \\
\hline \multirow{4}{*}{ Chiapas } & Tsotsil \\
\cline { 2 - 2 } & Tseltal \\
\cline { 2 - 2 } & Tojolab'al \\
\cline { 2 - 2 } & Zoque \\
\cline { 2 - 2 } & Cho'l \\
\hline Estado de México & Mazahua \\
\hline Puebla & Náwatl \\
\hline \multirow{2}{*}{ San Luis Potosí } & Náhuatl \\
\cline { 2 - 2 } & Tenek \\
\hline Veracruz & Náhuatl \\
\cline { 2 - 2 } & Totonaca \\
\hline Michoacán & Purhépecha \\
\hline
\end{tabular}

\footnotetext{
${ }^{45}$ Published on January 28, 2005, in the DiarioOficial de la Federación.

${ }^{46}$ See Footnote 45.

${ }^{47}$ Published on March 9, 2005, in the DiarioOficial de la Federación.

${ }^{48}$ Published on April 25, 2005, in the DiarioOficial de la Federación.

${ }^{49}$ Published on April 28, 2005, in the DiarioOficial de la Federación.

${ }^{50}$ Published on May 3, 2005, in the DiarioOficial de la Federación.

${ }^{51}$ The translation of the law into indigenous languages took place in states that have concluded a coordination agreement with the Ministry of Interior in religious matters: Chiapas, Michoacán, Nuevo León, Puebla, Querétaro, San Luis Potosí, State of Mexico, and Veracruz.
} 


\subsection{Interreligious Dialogue}

The State must encourage the development of the work of interreligious dialogue at different levels, for example, (1) At national level: the Interfaith Council of Mexico (founded in 1992 and as a civil association in 1995). (2) At state level: the Interreligious Councils of Chiapas (founded in 1992), Guerrero (founded in 2005), Nuevo León (founded in 2012), Michoacán (founded in 2016), Querétaro (founded in 2017), Veracruz (founded in 2017); and (3) At municipal level: the Municipal Evangelical Interfaith Council in Larrainzar (founded in 2007).

Also with respect to those who, exercising their right of self-determination, have decided not to belong to any interfaith council, as has been the case of the Christian Congregation of Jehovah's Witnesses.

On April 14, 2016, was inaugurated the first Encounter between Deputies and Interfaith Councils. ${ }^{52}$ Where the deputies pronounced themselves to elaborate a political agenda and initiatives to advance in a regulation of the Article 24 of the Constitution, whereas representatives of interreligious councils manifested the necessity to legislate in the matter of freedom of conscience and to improve the Law of Religious Associations and Public Worship, as well as its Regulations, in order to defend and promote religious freedom. Finally, it was assumed that Mexico has much to learn about religious freedom, since the 1992 reforms, although they recognized that right, said reforms "are still far from what Mexico has signed on human rights issues." 53

\subsection{Migration}

It should support religious associations that make use of their right to bring into the country ministers of worship and associated religious persons to participate in pastoral interchanges, as well as for international events held in Mexico, so it is necessary to reduce administrative obstacles on matters of inviting foreign ministers of worship into the country.

A positive aspect of the Mexican lay (laico) State has been to allow special diets in migration centers for people who, for religious reasons, make such request (Immigration Law, ${ }^{54}$ Article 107, II, second paragraph). This shows more openness to guaranteeing religious freedom.

\footnotetext{
${ }^{52}$ Proposals: (A) Develop a political agenda with these issues and advance in the constitution of a better society. (B) In no public school should be imposed or tought any religious line of thought. (C) Legislate on conscientious objection; improve both the Law of Religious Associations and Public Worship, and its regulations to defend and promote religious freedom. (D) That religious associations may own and operate radio and television stations. (E) That a fiscal legislation be elaborated according to the aims and objectives of the religious associations and churches, because they are not economic companies with the objective of trading.

${ }^{53}$ Promote secondary legislation on religious freedom and worship, which strengthens social values. See Bulletin No. 1341.

${ }^{54}$ Published on May 25, 2011, in DiarioOficial de la Federación.
} 
It requires greater collaboration between government and religious associations for the defense and the protection of the rights of migrants, especially of unaccompanied migrant children.

Finally, members of the Tohono otham indigenous people, as it is written on the other side of the Rio Grande; “tojonoo'otam," as pronounced on the Mexican side, are part of the 82,000 indigenous people, of whom some 42,000 reside in Mexico and around 40,000 in the United States, in the desert territory of Sonora and Arizona, divided by $120 \mathrm{~km}$ of border that was imposed without having been consulted. To that is added the construction of the "wall," proposed by Donald Trump, which represents a double offense for this indigenous population. ${ }^{55}$

\subsection{Official Recognition of Studies in Religious Institutions}

Since 1995, there has been a policy of openness by the Ministry of Education to recognize studies in religious matters, such as theology or religious sciences. Provided, they comply with the established legal requirements.

For example, official validity was recognized by the Ministry of Education for the curriculum in Judaic at the upper level (October 2012), which is unprecedented in the history of the Jewish Community of Mexico.

\subsection{Tax Matters}

The tax treatment of religious associations is regulated through a "general resolution" for all of them. However, the religious associations are not yet considered "nonprofitlegal entities" (personas morales sin fines de lucro) ${ }^{56}$; they are not authorized to receive donations deductible from income tax ${ }^{57}$; so this situation should be changed.

\footnotetext{
${ }^{55}$ See http://www.proceso.com.mx/488808/pueblo-indigena-separado-la-frontera-va-contra-murotrump.

${ }^{56}$ Although the Law of Income Tax (Ley del Impuestosobre la Renta) does not expressly refer to religious associations, it establishes that: "For the purposes of this Law, are considered non-profit legal persons (...) the following: XVI. Civil associations or societies with political, sporting or religious purposes."

${ }^{57}$ Cf. Tax Administration System (SAT). Rules for Religious Associations for the Fiscal Year 2019, of March 25, 2019.
} 


\subsection{Donations in Kind from Abroad}

Various religious denominations in Mexico, especially evangelical churches, ${ }^{58}$ have close relationship with churches from the USA who are willing to support them with donations in kind, especially: food, used clothing in good condition, medicines, toys, medical equipment, among others.

The current problems, in this case, are customs procedures that carry a high cost, which often turns out to be more expensive than the amount donated, and churches or religious communities do not have sufficient financial resources to cover such costs.

It seeks to guide religious associations to find the most appropriate way to receive donations from abroad. At present, they do this through civil associations for welfare; however, it insists that religious associations as "non-profit legal entities" also should come to be considered authorized donees.

\subsection{Labor Matters}

In this item, it is necessary to determine that ministers of worship are not employees or workers of religious associations, because there is a general assumption that considers religious associations as their employers, who therefore have to pay patronal contributions to the Mexican Social Security Institute (IMSS). That is a mistake.

\subsection{Security}

State authorities have recognized that religious associations, churches, and religious communities have much to contribute to Mexican society, to rebuild the social net (tejido social), especially in prevention matters, so their specific involvement in the National Security Plan of the federal government must be known. ${ }^{59}$ For now, they work on voluntary disarmament programs ${ }^{60}$ that are usually carried out in the atrium of Catholic churches.

It is important to highlight that "voluntary disarmament" has already been institutionalized by reforming the Law on Social Prevention of Crime and Violence for the Federal District, which was added with an Article 25 Bis, published on July 5,

\footnotetext{
${ }^{58}$ For example, in the State of Tamaulipas.

${ }^{59} \mathrm{Cf}$. Speech of Enrique Peña Nieto, Second Special Session of the National Public Security Council, December 17, 2012.

${ }^{60}$ For example, since 2007 voluntary disarmament programs are developed in the Federal District under different names: "Entrega voluntaria de armas de fuego" (voluntary handing over of firearms) and "Portufamilia, desarmevoluntario" (For your family, voluntary disarmament).
} 
2017, in the Official Gazette ${ }^{61}$; as well as the Organic Law of the Public Security Secretariat of the Federal District, whose article 3 was added with a fraction XXX Bis, published on July 5, 2017, in the Official Gazette. ${ }^{62}$

Finally, on August 25, 2015, for example, the government of the state of Veracruz and religious organizations signed an agreement to prevent crime.

\subsection{Reservations to International Treaties}

It is necessary to review and to update the interpretative declarations and reservations made at the time by the Mexican State in concluding international treaties relating to religious freedom and ministers of worship.

\subsection{Religious Tourism}

At the federal level, the Ministry of Tourism (SECTUR) has conducted coordinated actions with state governments and non-governmental agencies to strengthen religious tourism in Mexico. This Ministry reported that Mexico is one of the most visited nations of the world thanks to the architectural, artistic, and cultural wealth of its sanctuaries, comparable in the arrival of tourists to other world religious centers. ${ }^{63}$

At the local level, on June 14, 2014, the "religious tourism program" was presented by the Federal District Government. The program involves three routes for visitors: (1) The Guadeloupian way (El caminoguadalupano), (2) Bastions of Catholicism (Baluartes del catolicismo), and (3) Ways of faith (Caminos de la fe). This program considers not only Catholic, but also Buddhist, Jewish, Methodist, Mormon and Orthodox temples.

\footnotetext{
${ }^{61}$ Ley de Prevención Social del Delito y la Violencia para el Distrito Federal. Artículo 26 Bis. El Gobierno de Ciudad de México, atenderá el desarme voluntario, a través de las acciones y/o Programas conforme a los lineamientos que la Secretaría de Desarrollo Social emita para su implementación. ${ }^{62}$ Ley Orgánica de la Secretaría de Seguridad Pública del Distrito Federal. Artículo 3 ○-Corresponden a la Secretaría las siguientes atribuciones: XXX BIS. Coadyuvar con la Secretaría de Desarrollo Social de la Ciudad de México en el desarrollo de la Acción Interinstitucional denominada "Por Tu Familia, Desarme Voluntario" y su modalidad "por Tu Familia, Desarme Voluntario te Acompaña Desde Tu Casa", para generar un ambiente de paz, con la finalidad de establecer acciones de prevención delictiva a través de promover la cultura de la paz y no violencia.

${ }^{63} \mathrm{https}: / / \mathrm{www}$. gob.mx/sectur/prensa/mexico-entre-los-paises-mas-visitados-por-turismoreligioso-sectur.
} 


\subsection{Environmental Education for Sustainability}

The Ministry of Environment and Natural Resources (SEMARNAT), in coordination with the Ministry of Public Education (SEP), has developed since 2008 a program to encourage the called "green schools," which perform actions and environmental management strategies to combat climate change.

In 2012, for example, the Tarbut Hebrew College was recognized as "Green school. Environmental leader" and the Israeli College of Mexico as "Green school," implying that in the field of environmental sustainability, institutions representing a diversity of religions are taken into consideration for such programs.

\subsection{Resolution of Religious Conflicts}

The General Directorate of Religious Associations must address in a more timely and prudent manner the conflicts on religious intolerance matters that are characterized by the combination of several factors, including political, partisan, economic and agrarian, also caciquism (cacicazgo). These have even instrumentalized religion to cover up political actions or justify violence, making it difficult to identify intolerance as purely religious and to achieve an immediate peaceful solution to the conflicts.

\section{Cases}

According to a typology of violations of religious and ideological freedom by State and non-State agents $(2016)^{64}$ we want to highlight here only two recent aspects for the case of Mexico, related to: constitutive register of religious associations and conscientious objection.

\footnotetext{
${ }^{64} \mathrm{Cfr}$. Report of the German federal government on the world situation of religious freedom (June 9, 2016): (a) Criminal sanctions. (b) Administrative obstacles. (c) Legal sanctions in family and inheritance matters. (d) Limitations to the public exercise of religion. (e) Prejudices and social stigmatization. (f) Obstacles in recognition and registration of religious associations. (g) Religious praxis and way of life. (h) Religious education. (i) Care of real estate intended for religious purposes. (j) Religious freedom of the indigenous peoples. (k) Conscientious objection to military service. (l) Religious freedom and freedom of opinion. (m) Discrimination based on religion and ideology. (n) Access to public service and public positions. (o) Access to education. (p) Access to the private economy. (q) Limitations to religious freedom based on family law and inheritance.
} 


\subsection{Constitutive Register and Native American Church of Mexico}

The General Directorate of Religious Associations, of the Ministry of the Interior, denied registration to the Native American Church of Mexico as a religious association, for failing to comply with requirements and deadlines. This decision was based in Article 9 of the Regulations of the Law of Religious Associations and Public Worship.

Faced with the refusal to register, the Supreme Court of Justice of the Nation in the amparo under revision 267/2016, determined that the formal requirements required by the law for the constitutive registration as a religious association cannot be understood as insurmountable barriers, through which the validity is questioned or the ideological content of a certain religious belief. That study would imply invading an area alien to its powers as authority. In other words, the authority is not entitled to question the content or practices that give life to a certain religious ideology, but must limit itself to verify the formal requirements imposed by the law for registration.

\subsection{Conscientious Objection to Blood Transfusions}

In the weighing of the right to religious freedom with the human right to life, a federal judge $^{65}$ (Eighth District Court in the State of Chihuahua) ordered that a minor suffering from leukemia received a blood transfusion once the alternative medical treatments had been exhausted, by virtue of which the minor professed the religion Jehovah's Witnesses.

With the sentence, the fundamental right of religious freedom was revised, as well as the rights to a second opinion, informed consent and decision making, regarding medical treatments. However, due to the lack of maturity of the girl to understand the scope of the medical act on her health, the right to life was privileged; so the doctors were authorized to perform the necessary treatments to protect the life of the minor, including blood transfusion.

It was also determined that the corresponding reforms were made for the creation of a protocol and procedure so that the doctors, in case of the refusal of the consent of the parents to administer treatments to minors, appear before a judge to argue the case, and it is that judge who analyzes the circumstances, listens to the parties and resolves the corresponding.

\footnotetext{
${ }^{65}$ Judge Mauricio Fernandez de la Mora, head of the Eighth District Court in the State of Chihuahua, granted the "amparo" to a woman of the Rarámuri ethnic group, who professes the religion Jehovah's Witnesses, for blood to be transferred to her five-year-old daughter, affected by leukemia, provided other means or alternative treatments have been exhausted, such as those proposed by various doctors, including oncologists at the Cancer Center of Chihuahua. See Nota Informativa: DGCS/NI: 45/2017, Poder Judicial de la Federación. Ciudad de México, a 13 de julio de 2017.
} 


\section{Conclusion}

With the amendments to Articles 24 and 40 of the Mexican Constitution, it is clear that a truly secular State (lay/laico State) has to facilitate the effective exercise of religious freedom. The State has to generate a public policy that engages a significant change in the way in which it manages the religious diversity, which makes it comprehensible to decision makers that this field is not in the sphere of persuasion or negotiation but in the necessary observance of rules that ensure religious freedom effectively.

This management is expressed in developing actions and strategies for the implementation of in force legal instruments, consistent with Mexico's international obligations in this regard; plus informed dialogue between State authorities and religious actors in the meaning of full religious freedom and the responsibility that implies its exercise in the context of a secular State (lay/laico), respectful of religious diversity.

\section{References}

Lima Torrado J (2000) Desobediencia civil y objeción de conciencia, 1st edn. National Commission for Human Rights, Mexico

Listl J, Dietrich P (1994) Handbuch des Staatskirchenrecht des Bundesrepublik Deutschland, 2nd edn. Duncker \& Humblot, Berlin

Medina González MC (2005) Das Religionsrecht in Mexiko. Volumes I and II. LIT, Münster

Nowak M (1989) UNO-Pakt über bürgerliche und politische Rechte und Fakultativprotokoll. CCPRKommentar, Engel, Norbert P, Strassburg

Wahrig G (1997) Deutsches Wörterbuch. Bertelsmann Lexikon, Gütersloh 